\title{
INSTITUTIONAL TRANSFORMATION OF MADRASA OF MUSLIM MINORITY IN THAILAND
}

\section{Ismail Suardi Wekke}

Sekolah Tinggi Agama Islam Negeri (STAIN) Sorong

Jl. Basuki Rahmat No.40 Kota Sorong, Papua Barat, Indonesia, 98917

Email: iswekke@gmail.com

\section{Muhammad Ashrori}

Sekolah Tinggi Agama Islam Negeri (STAIN) Sorong

Jl. Basuki Rahmat No.40 Kota Sorong, Papua Barat, Indonesia, 98917

Email: mashrori@gmail.com

\section{Budianto Hamuddin}

Universitas Lancang Kuning, Pekanbaru, Indonesia

Jl. Yos Sudarso No.KM. 8, Rumbai, Pekanbaru, Riau, Indonesia, 28265

Email: budihamuddin@unilak.ac.id

Received: 01, 2018. Accepted: 06, 2018. Published: 06, 2018.

\begin{abstract}
The article discusses the history of madrasa in the Southern Province of Thailand. The Muslim Malay community in Southern Thailand is an inseparable part of the Republic of Thailand. Historically, the Muslim Malay community are indigenous people who have embraced Islam since the 13th century, and even reachedits peak of glory during the reign of Pattani Sultanate. The discussion specializes in the history of madrasa in the region. The study uses historical approach. The article illustrates that the beginning of the emergence of madrasa was motivated by the disagreement among Muslim Malay community against Thai governmental policies. Haji Sulong was the founder of the first madrasa in Southern Thailand in 1933 named "Madrasah Al-Ma'arif Al-Watattaniah Fattani" as a manifestation of his intention to improve the socio-economic welfare of Muslim Malay community through education. Finally, the article discusses the institutional dynamics of Muslim minority madrasa and the development in relation to the identity and capacity of community.
\end{abstract}

Keywords: Historical, Madrasa, Muslim Malay, Thailand.

\begin{abstract}
ABSTRAK
Artikel ini membahas sejarah madrasah di Provinsi Thailand Selatan. Komunitas Muslim Melayu di Thailand Selatan adalah bagian tak. terpisabkan dari Republik. Thailand. Secara historis, komunitas Muslim Melayu adalah penduduk. asliyang telah memeluk Islam sejak abad ke-13 dan babkean memperoleh masa keemasan puncaknya di masa kekuasaan Sultan Pattani. Pembahasan ini difokuskan untuk mengkaji sejarah madrasab di wilayah tersebut. Penelitian ini menggunakan pendekatan historis. Artikel ini mengilustrasikan bahwa di awal kemunculannnya, madrasah merupakan respon terhadap perselisihan antara komunitas Muslim Melayu dengan kebijakan pemerintaban Thailand. Haji Sulong adalah pendiri madrasah pertama di Thailand Selatan pada tabun 1933 yang dinamai "Madrasah Al-Ma'arif AlWattaniah Fattani" sebagai manifestasi dari keinginannya untuk meningkatkan kesejabteraan sosial ekonomi komunitas Muslim Melayu melalui pendidikan. Pada bagian akbir, artikel ini membahas tentang dinamika institusional madrasah minoritas Muslim dan perkembangannya dalam kaitannya dengan identitas dan kapasitas komunitas.
\end{abstract}

Kata Kunci: Sejarah, Madrasah, Muslim Melayu, Thailand. 


\section{INTRODUCTION}

Islam becomes the biggest religion in Southeast Asia, especially Indonesia, Malaysia, and Brunei. However, in several countries such as Thailand, Cambodia, Vietnam, Myanmar, and Singapore, Islam is the minority. Muslim population in the eleven Southeast Asian countries spread across various regions with diverse cultures. Therefore, the picture of Islam in Southeast Asia is not in line between one another. In the Brunei establishment, Muslim society enjoy the facilities in extending educational institution through sultanate attachment (Lubis \& Wekke, 2016). The diversity of Islam in Southeast Asia is proven in the diversity of ritual cultures, clothings and other religious traditions. In this case, clothing as a product of a culture is closely related to religious and customary rituals (Houben \& Schulze, 2012).

Before Islam entered Southeast Asia, the predominant communities for centuries were Hindus and Buddhists. Hinduism and Buddhism became the majority religion of Southeast Asia, especially the Malay people for 800 years (Zakaria, 2012). The entry of Islam to Southeast Asia region was started with the trading voyage of Muslim merchants from Arab and Persia to the region through South Asia in the early 7th century. At the beginning of the 9th century there had been settlements of Muslim merchants residing in Malacca, Aceh and the Malay Peninsula (South Siam is now known as Southern Thailand). Azra (2002) argues that the entry of Islam to Thailand was estimated on the 10th or the 11th century AD in Southern Thailand region or precisely in Pattani region. Islam also entered the region of Pattani reign through Muslim merchants from Arab and India.

Thailand, Sri Lanka and Burma are the three regions in which Muslim become a minority, because the major population of the three countries are Hindus and Buddhists. Muslim population in Thailand can be divided into two groups, the first group is Muslim natives of Thailand and the second one is Muslim Malays who migrated and live in the Southern part of Thailand. This migration gives an impact on cultural, linguistic, ethnic and political exchanges. In the Southern Thailand region of Pattani, $80 \%$ of the population is Muslim with approximately 700,000 people (Yusuf, 1999). In Thailand, most of Muslims are Malay people who have lived with Malay standards. They scatter around four areas in Thailand: Pattani, Yala, Narathiwat, and Satun (Kraus, 1984). However, they are not the only Muslim Thailand. There are some Muslims in Thailand coming from such countries as India, Pakistan, Bangladesh, etc. Even so, in Thailand, Muslims are in minority in comparison with people with other religions.

From the region, Islam was spread to the surrounding areas in some parts of Southeast Asia such as Sumatra, Java and Kalimantan. The entry of Islam to Southeast Asia regions brought new conditions to the communities. Before the entry of Islam, Hinduism and Buddhism were functioned as the official religion of the reigns in the regions. After Islam was widely accepted as the community religion, especially through encounter with Malay communities who inhabited the islands of Southeast Asia region, Islam has eventually become the official religion. For example, Kelantan, Perlis, Pattani, Kedah, and Trengganu. The majority of Thai Muslim live in the areas of Pattani, Yala, Nalatriwat and Satun (Kraus, 1984). In the mid-17th century, Muslim merchants from Persia came to Ayutthaya to trade and eventually married locals and made settlements in the area. Furthermore, King Songtham Ayutthaya (16101628) was appointed to be the leader of Muslim communities as Chularajmotri (Islamic Syaekhul) to oversee the activities of Muslim in the territory of Thai reign. Islamic institution will not stand alone without environment condition (Wekke \& Sahlan, 2014). The distribution of religions in South East Asia is described in Figure 1. The Figure clearly shows that Islam is still the religion of minority in Thailand (purple area). 


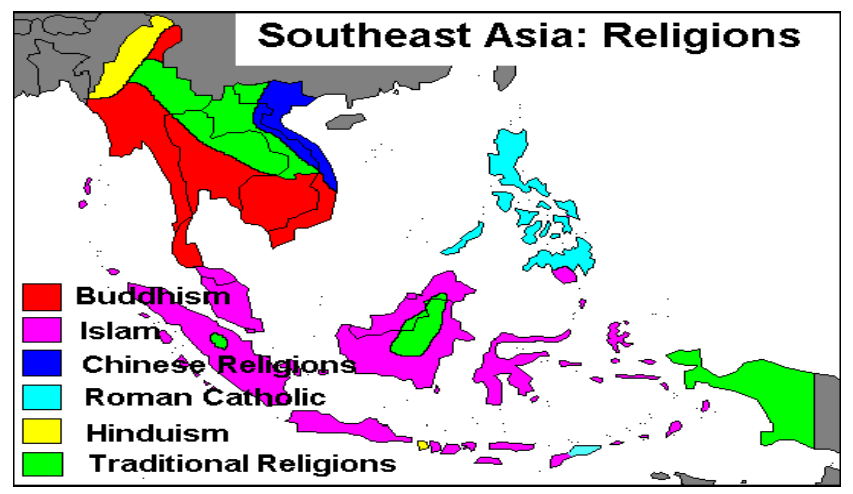

Figure 1. The Distribution of Religions in South East Asia.

Muslims in Thailand face diverse life issues. Cultural, religion and political situation diversities lead to frequent conflicts. Particularly in the territory of Pattani in which conflicts between religious and military are frequent. Several problems faced by Muslims in Thailand include theft, murder, radical and extreme organizations, and political condition and climate which aggravate the situation and the governmental treatment against Islamic minorities in Thailand (Haemindra, 1976). Separatist movements and conflicts which occurred in Southern Thailand were conducted by the majority of Muslim population of 3.2 million, or about five percent of the Thai population. About 3.500 people have died since the outbreak of conflicts and separatist movements in Southern Thailand. The crisis in Southern Thailand has a significant impact on the security of the Southeast Asian regions (Aslam, 2008). Politics, discrimination and manipulation factors lead to aggravated conflicts (Islam, 1998).

The studies of Muslim minorities in Southern Thailand, in terms of history, culture, education and politic have been conducted by experts. However, there have not been many specific articles on madrasa, especially about the history of madrasa in Southern Thailand. The researcher concludes that there are at least three background aspects of the establishment of madrasa in Southern Thailand, which are: 1) The importance of modernization in current Islamic education to advance Muslims; 2) The intervention of Thai central government (Bangkok) in Islamic Education System due to the enactment of reform and modernization in all fields; and 3) An effort to improve the socio-economic life of Muslim Malays in Southern Thailand. The distribution of Muslim population in Thailand is presented in Figure 2.

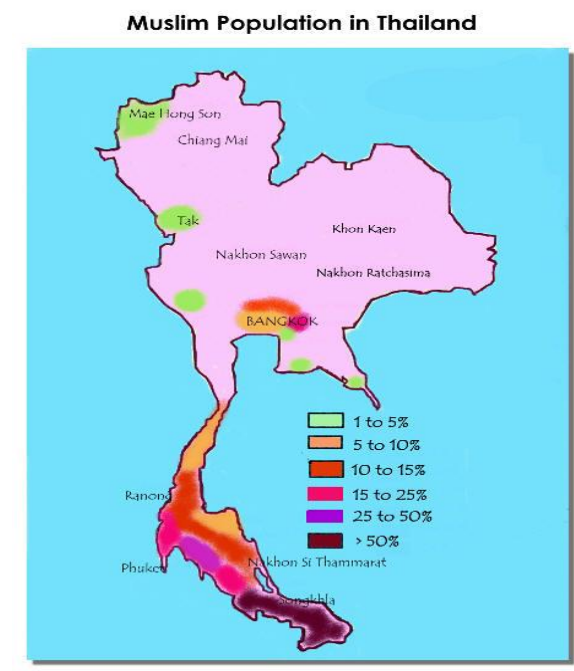

Figure 2. The Muslim Population in Thailand. 


\section{METHOD}

This article uses a historical approach, with book survey techniques. Articles reviewed are the related articles by previous researchers, primarily Thai education are History and Politics of The Muslims in Thailand (Aphornsuvan, 2003), The Muslim Malay community in Southern Thailand: A "Small people" Facing Exsistential Uncertainty (Von-Feigenblatt, 2010), Southern Thailand: A Cosmic War?) (Andre, 2008), Religious Minority, Education and Separatism in South Thailand (Sarkar, 2014), and Religiosity and Social Problems among Muslim Adolescents in Southern Thailand (Sateemae, Abdel-Monem, \& Sateemae, 2015). The final stage of this series of activities was a focused discussion involving researchers at STAIN Sorong to ensure the reliability of data obtained.

\section{RESULTS AND DISCUSSION \\ Social History of Madrasa in Thailand}

Traditional Islamic education is an integral part of the spreading and cultivating process of Islamic teachings in every region in the world. In Southeast Asia regions such as Indonesia, the traditional Islamic education is known as pondok pesantren, while in Malaysia and Thailand is ponok, and in Africa such as Nigeria, Egypt and other Muslim-majority countries is madrasab (Hashim, 2011). Traditional Islamic education institutions become the most important part in the development and spreading of Islamic teachings.

Pattani region was once the reign of Lankasuka, one of the ancient Malay reigns in which since the beginning of the century $\mathrm{AD}$, in its prosperity, was one of the powerful reigns and dominated the territorial waters which became the route of ship crossing in the territorial waters of Gult from Siam, a south region of Vietnam, to Malay waters (Man, 1985). The merger of Pattani Sultanate into Thai governmental system in 1902 was not only about the political act of power centralization by Bangkok, but also the determination of decisions on religion, culture and custom of Muslim Malays, which was then replaced by Buddhist cultures. The important thing was the elimination of sharia (Islamic law) and Malay Custom (Malay customary law) which were previously the basis of Islamic practice in life. Although Pattani was under the authority of a King, the King ruled on the basis of Islamic sharia and Malay Custom Institutions. The mosque functioned as a worship place and governmental administration center as well as village hall, while ponok functioned as the center of education for the community. Mosque and ponok were two important institutions for the sustainability and prosperity of all Muslims.

The merger of Pattani Sultanate into the Republic of Thailand in 1902 made the central government's attention to the region more dominant. The central policy to reform in all fields has made the Muslim Malay community in southern Thailand region as the object. Particularly, education (according to the central government) is one of the means to achieve modernization. In other regions of Thailand, local Buddhist monks and temples along with governmental officials have undertaken educational reforms. Whereas Malay Muslim Communities have their own distinctive teaching system and language called ponok. They use Malay Language (Jawi) and Arabic Language in instruction (education) and writing Islamic lessons. Islamic teaching (education) was done in the local mosques before the establishment of ponok.

Since then, a process of assimilation called "Siamization" began to occur. This has a significant negative effect on the influence of Islamic political leadership and the authority of ummah and religious leaders. The king loses authority, political power, and no less important, economic resources. Meanwhile, the roles of ulema are getting smaller because of the limitation of Islamic Sharia. This detrimental process resulted in several local incidents in the form of a rebellion against the center of power in Bangkok led by ulemas in $1910 \mathrm{AD}$ and $1911 \mathrm{AD}$ (Esposito, 1995). With the enactment of low education regulations in $1921 \mathrm{AD}$, Muslim children are required to attend Thai state schools. They are required to use Thai and Malay Language began to fade. Various communities began to suspect this "Siamization" policy as Thailand's attempt to undermine the ethnic and culture of Islamic Malay. As a result, during 
$1922 \mathrm{AD}$ and $1923 \mathrm{AD}$ there were several local political turbulences in various places. Seeing the unfavorable development and also the potential of British interference, the central government in Bangkok then took the path of compromise by loosening their various social and cultural policies toward the Islamic community of Pattani.

When educational reforms entered the Muslim Malay community, they were asked to read and write in Thai Language and oriented towards secular subjects and even on Buddhism. Such policies and practices (changing the curriculum and using Thai language as an introductory language in education) make the education for Malay Muslims in south region is done in mosque and ponok (Aphornsuvan, 2003) known as Pondok Pesantren in Indonesia (Bashori, 2017). The history of Islam in Thailand region is a historical record of the glory of Islam in the past. Since the 13th century, Islam has established a strong relationship with the Malay world. In that period Pattani was a tributary of Ayutthaya, its strategic geographical position made Pattani accepting sufficient special autonomy. This made Pattani more receptive to the influence of the Muslim Malay world. Southern Thailand (Pattani), since the $13^{\text {th }}$ century, has strong relationship with the Islamic world (Islamification), along with the Northern Malay Sultanate of Kedah, Kelantan and Trengganu, compared to their northern neighbors such as Siam or now Thailand. Islam entered the north region of Thailand through Muslim merchants from Persia. In the 16th and 17th centuries of the Ayutthaya era, Persian Muslim merchants brought Shia Islam to Thailand through trade relationships. The Persian Muslim merchants were concentrated in the urban region of Northern Thailand (Bangkok, Ayutthaya, and Nakhon), they had strategic roles not only in their dominant trade but also in the government and even the Ayutthaya reign's marine.

Between the $15^{\text {th }}$ and $18^{\text {th }}$ centuries, Pattani was also developed as a center of trade, but more specifically the splendor of Islamic rule (Där al-Isläm) which was recognized worldwide. Pattani also emerged as the center of Islamic studies in Southeast Asia. As described before, according to some historical evidence, Islam has been presented in the Pattani area of Southern Thailand, earlier than the $13^{\text {th }}$ century and certainly before the ruling time of King Ramkhamhaeng (1279-1298). This could be possible, because of the close relationship between Saudi, the heart of Islam, and Southeast Asia, which was then served by Pattani as a trading center.

The Islamic modernist movement entered Southern Thailand in the 19th century, which was pioneered by Muhammad Abduh from Bangkok. Southern Thailand especially the four Provinces of Satun, Songkhla, Pattani, Yala and Narathiwat have their own history of this Islamic modernist movement. That was when the enactment of the central governmental policy at the end of World War II, in 1939-1945, the new policy of central government to protect Islam (in order to avoid the gap) then formed a supervisory body for Muslims as the official act of Thai central government for the Muslim Malay community in Southern Thailand. On the other side, the policy reaps strong protests from the Muslim Malay community of Southern Thailand.

This is because the educational activities are determined by the central government and requiring the Islamic ponok schools to follow the policy. The rejection of Muslim Malay community is quite reasonable, because as a Malay nation, they feel they have the right to maintain their own identity as Muslims, and to study their religious teachings as widely as possible. If the central governmental policy of Thailand (Bangkok) is taken for granted they feel their identity as Muslims are threatened. The policy includes the obligation to use Thai Language as an introduction to religious studies, and each school is obliged to teach the history of Thailand (Siam) which is certainly incompatible with the history of Malay Muslims living in Southern Thailand.

In other words, the essence of the rejection is due to the intervention of Thai central government against the Malay Muslims of Southern Thailand on Siam's national history, and the teaching of national symbols, and Thai Language as a national language, also because Malay 
Language is only used as a religious language. The Muslim Malay community rejects the policy, fearing their children are interested in Buddhism, and there is no room for studying Islamic religion in Siamese Language. Also as a reaction to the possibility of colonization; religion, language and ancestral of cultural heritage which still be held by the Muslim Malay community in the region.

In 1933, an Islamic modernist figure in Southern Thailand, Haji Sulong bin Abdul Kadir, founded an Islamic school (madrasa) in Pattani named "Madrasah Al-Ma'arif Al-Wattaniah Fattani". As an Islamic modernist he does not agree with the stagnation in the world of Islamic education, he argues that the current system of Islamic education (ponok system) is necessary to get a change (modernization in education world) but he also disagrees with the intervention of Thai central government on Islamic education (ponok) in excess (incorporating compulsory curriculum of Thai (Siamese) language, Siamese history and Buddhist Siamese symbols. As a manifestation of his passive resistance to the central governmental policy (Thailand) towards Muslim Malay community in Southern Thailand, as well as a form of the seriousness of his intention to improve the socio-economic life of Muslim Malay community in Southern Thailand, then the school was established (Sarkar, 2014).

The Islamification in Southeast Asia regions by Arabic and Persian merchants had several stages, starting with communal Quran reading in the mosque to the establishment of Islamic educational institution, ponok. This is the case in Southern Thailand (Narathiwat, Pattani, Satun, Songkhla and Yala). Traditional Islamic educational institutions such as ponok played an important role in the transmission of knowledge from one generation to the next and also in the spreading of religious values through education to save religion. From the time of the Islam spreading to the region of Southern Thailand, Islamic schools were known as ponok (Sateemae et al., 2015).

Ponok in Southern Thailand is the forerunner of modern Islamic school, madrasa. On its course, ponok experienced clashes with the policies of Thai government. This is due to the enactment of reforms in all fields by Thai central government in 1902. As educational reforms entered the Muslim Malay community, they are asked to read and write in Thai Language and oriented towards secular subjects and even to Buddhism. However, Muslim Malay community have their own distinctive teaching system and language. They use Malay or Arabic Language in instruction and writing Islamic lessons. Islamic teachings (education) were done in the local mosques before the establishment of Islamic schools (madrasa or ponok) (Aphornsuvan, 2003).

In addition, the history of madrasa in Southern Thailand was inspired by the Islamic modernist movement which entered Southern Thailand in the 19th century. The movement was pioneered by Muhammad Abduh from Bangkok. Thai central governmental policy of enacting reforms in all fields including education world was also the cause of birth of Islamic education modernization from the classical model of ponok into modern educational institutions (modern Islamic schools or madrasa). In 1933, Haji Sulong bin Abdul Kadir established an Islamic school (madrasa) in Pattani named "Madrasah Al-Ma'arif Al-Wattaniah Fattani”" as a form of passive resistance against the policies of central government (Thailand) toward Muslim Malay community in Southern Thailand, also as a sincerity of his intention to improve the socioeconomic life of Muslim Malay community in Southern Thailand (Sarkar, 2014).

The birth of madrasa in Southern Thailand was also the answer to the central governmental policies toward Islamic education reforms. As the assimilation policy of central government under the dictatorship of Field Marshall Phibunsongkram spread throughout Thai central government (including Southern Thailand), then Thai central government gradually sought to bring ponok into an education system which has been regulated by the central government (secular system) and out of ponok's private system to run schools offering secular (general) subjects along with religious people (Arphattananon, 2011; Yong, 2012). Ponok which 
adopted the central government policies created institution in it (madrasa or modern Islamic school). Madrasa teaches additional subjects (general lessons) in addition to religious lessons (Sateemae et al., 2015).

Since the 2000s, the dynamics of Islam in Thailand have been influenced by three transnational Islamic movements, there are the tabligh worshipers, the Muslim Brotherhood who become partners of the Young Muslim Association of Thailand (YMAT) and the international network of Salafi reform movement (Ibrahim, 2012).

One of the biggest movements of Islam expansions in Thailand is that conducted by the Tabligh Jama'at. This type of organization focuses heavily on rituals. Some of them even leave their house (along with their wife and children) to do dakwah and be on mosque tour. They seem to strive in in secular countries such as Thailand where Muslims are the minority. The movement emerged in India in the late 1920s.

\section{The Dynamics of Madrasa in Thailand}

The discussion of the three journals which were analysed by the researcher is not specific to the history of madrasa in Southern Thailand. In Thanet Aphornsuvan's (2003) journal History and Politics of the Muslims of Thailand, the discussion of madrasa (Islamic school) is started with the intervention from central government to reform in all fields of life. In Section II, page 17 which is: "Started from the centralization policy under King Rama V, to integrate the Muslim population into Thai government. The government was aware of the religious differences between Thailand and Muslims, thereby allowing local Pattani elites to rule with Islamic law."

In 1902, the first ever reform by Chulalongkorn was "no legal decision from the Islamic court, the law must be established through the central government", it means that the King wanted a single legal system applicable to the whole country. However after the Merger of Pattani Sultanate territory to Thaigovernmental system in 1902, that is not only about a centralized political act of power by Bangkok, but also central intervention to region in which the principles of religion, culture and custom of Muslim Malays are then replaced with Buddhism practices. The most important is the abolition of Sharia (Islamic law) and Malay Custom (Malay customary law), which were the basis of Islamic practice in life. Although Pattani was under the rule of a King, the King ruled on the basis of Islamic Sharia and Malay Custom institutions. The mosque functioned as a worship place and governmental administrative center and village hall, while ponok functioned as an educational center for the community. Mosque and ponok are two important institutions for the existence and prosperity of all Muslims.

The merger of Pattani Sultanate into the Republic of Thailand in 1902 made the central government's attention to the region more dominant. The central policy to reform in all fields has made the Muslim Malay community in Southern Thailand region as the object, particularly in education. It is because according to the central government, education is one of the means to achieve modernization. In other regions of Thailand, local Buddhist monks and temples along with governmental officials have undertaken educational reforms. Whereas Malay Muslim Communities have their own distinctive teaching system and language. They use Malay or Arabic Language in instruction and writing Islamic lessons. Islamic teaching (education) was done in the local mosques before the establishment of ponok school. When educational reforms entered the Muslim Malay community, they were asked to read and write in Thai Language and oriented towards secular subjects and even on Buddhism. Such policies and practices (changing the curriculum and using Thai language as an introductory language in education) made the education for Malay Muslims in south region is done in mosque and ponok (Aphornsuvan, 2003).

The discussion of madrasa is started with the history of Islamic education institution ponok then modern Islamic schools, madrasa. The discussion is as follows: "Since the entry of Islam into Southern Thailand region to date, traditional Islamic educational institution such as ponok played a big role in the transmission of knowledge from one generation to the next and also in 
the spreading of instruction through education to save religion. Ponok also appeared as a major provider of religious guidance for the whole Muslim Malay community in the region. Ponok in Southern Thailand was a Muslim Malay identity, besides, ponok also served as an important institution in maintaining the history, language and culture of Muslim Malay community. Since the $19^{\text {th }}$ century onwards, Pattani reign has been the center of Islamic education development.

In the early $20^{\text {th }}$ century when the religious awakening was ongoing throughout the Muslim world, Pattani region had the greatest number of Islamic schools, ponok. Pattani is one of the regions affected by Islam (the Malay world of Siam) since the $13^{\text {th }}$ century, along with northern Malay sultanates, Kedah, Kelantan and Trengganu. From $15^{\text {th }}$ until 18 th century Pattani was also one of Islamic studies centers in Southeast Asia. There were some historical evidences that Islam hasbeen presented in Southern Thailand before the $13^{\text {th }}$ century, before King Ramkham. The Islamic reformist movement entered Southern Thailand in the $19^{\text {th }}$ century, pioneered by Muhammad Abduh from Bangkok. Educational activities are determined on the national history of Siam, and the teachings of national symbols and Thai as a national language, while Malay Language is only used as religious language.

Islamic education in Southeast Asia reflects the diversity of Islam in the world and has an important role in bridging the teachings of Islam to synergize with local cultural teachings. However, the pattern of an Islamic educational institution will be influenced by the dynamics of religious politic which will affect the education policy in a Country and the ideological factors adopted by the educational institutions. All of them will determine the teaching curriculum of an Islamic educational institution (Liow, 2009).

The Muslim Malay community rejects the policy, fearing their children are interested in Buddhism, and there is no room for studying Islamic religion in Siamese Language. Also as a reaction to the possibility of colonization; religion, language and ancestral of cultural heritage which still be held by the Muslim Malay community in the region. In 1933, Haji Sulong founded an Islamic school (madrasa) in Pattani named "Madrasah Al-Ma'arif Al-Wattaniah Fattani" as a manifestation of his passive resistance to the central (Thailand) governmental policy towards the Muslim Malay community in Southern Thailand, as well as a form of the seriousness of his intention to improve the socio-economic life of Muslim Malay community in Southern Thailand." (Sarkar, 2014).

Suhaimee Sateemae's (2015) journal entitled Religiosity and Social Problems among Muslim Adolescents in Southern Thailand contains the discussion about modern Islamic educational institution, madrasa, which is started with the history of a classical Islamic educational institution called ponok, then about madrasaon page 7 . The Islamic educational tradition of ponok in Southern Thailand had been started since the spreading of Islam to Pattani $\left(15^{\text {th }}-18^{\text {th }}\right.$ century), which developed significantly and got encouraging results, in which Pattani became the Islamic science center for the whole Southeast Asia region at that time (Madmarn, 2009). Ponok had long been known as an institution with central role in the culture of Muslim Malay community, this institution served as an Islamic educational institution before the birth of modern Islamic school, madrasa.

Ponok was the basis of Muslim Malay forces in maintaining religion, culture and custom. Hence ponok always taught the basic principles of religious, ethic, and moral knowledges, thus ponok functioned as an institution in charge of educating Muslim Malay generations in all aspects of Islam and as the defence center of identity and life (Firdaus \& Wekke, 2017; Liow, 2009; Madmarn, 2009). Ponok became a popular educational institution for Muslim Malay community in Southern Thailand, especially in decades. As the assimilation policy of central government under the dictatorship of Field Marshall Phibunsongkram spread throughout Thai central government (including Southern Thailand), then Thai central government gradually sought to bring ponok into an education system which has been regulated by the central government 
(secular system) and out of ponok's private system to run schools offering secular (general) subjects along with religious people (Arphattananon, 2011; Yong, 2012). Students entering ponok varied from the age of 7 years old until adults who wanted to deepen their Islam in several cases (Firdaus \& Wekke, 2017). 7-year-old children were prioritized to be able to read Quran well and correctly (Rabasa, 2005). Ponok which adopted the central government policies created institution in it (madrasa or modern Islamic school). Madrasa teaches additional subjects (general lessons) in addition to religious lessons. Religious lessons are usually taught for half a day (for example, from 8 am to noon), such as Oneness of God, Islamic jurisprudences, hadith (prophetic traditions), morals (ethics), Quran, Islamic histories, and Arabic and Malay languages. The other side of the school day (e.g., 01:00-04:00) is specific for the general (secular) subjects, including mathematics, physical and social sciences, occupational skills, arts, Thai and English languages, and physical activities/sports (Sateemae et al., 2015).

Like in other countries which have madrasa, madrasa was first viewed as a threat rather than a solution. People tended to think that those who go to madrasa will have extreme and radical thoughts about Islam. Some of them are so extreme that are willing to do suicidal bombing in public places. However, as time goes by, madrasa have proven to be a solution instead. Striving with the modernity while still maintaining the Islamic values as the core of the curriculum madrasa can create students with good knowledge as well as good characters. Not only have the graduates of madrasa proven that they are competitive with those from public schools, they can also outperform them in several aspects such as academic, economic, etc. (Liow, 2005).

\section{The Reasons of Institutional Transformation of Madrasa in Thailand}

In the history of the establishment of madrasa, a modern Islamic school, at least there are three causes of it: First, The intervention of central government to reform in all fields, Second, The adoption of a single legal system by the central government (the abolition of Islamic law and Malay customary law which had become the basis in everyday life practice), Third, The Islamic modernist movement brought by the santri of ponok who studied in Mecca, and upon their return established the modern Islamic school of madrasa (Aphornsuvan, 2003).

The history of the establishment of madrasa in Southern Thailand has at least three background factors, which are First: Islamic modernist movement, Second, Central governmental intervention to the implementation of reforms in all fields including education, Third: As an effort to improve the socio-economic life of Muslim Malays in Southern Thailand through education. The similarity lies in the discussion of the history of ponok which is a classical Islamic educational institution, before eventually the institution changed itself with the modern system. The combination of traditionalism and modernity emerge a dynamic institution (Wekke, 2015).

Sateemae (2015) states that although the discussion focuses on the religious behavior of Muslim adolescents and its relation to social problems, it also discusses ponok as the beginning of madrasa which developed as modern Islamic school. Even within a few decades, ponok has made Thailand as the Islamic education center in Southeast Asia. As for the history of the establishment of madrasa, it is the result of central government policies under the dictatorship of Field Marshall Phibunsongkram which is gradually trying to bring ponok into the governmental system (secular educational institution) (Arphattananon, 2011). This is one of the reasons for the emergence of madrasa in Southern Thailand which is central governmental intervention which seeks to bring ponok into the modern educational system (modern Islamic schools) (Sateemae et al., 2015). Finally, the establishment of madrasa could not be extended without the participation of society (Wekke, 2015). Therefore, the element of pesantren (Islamic education) should place the society in to the system of management.

The institutional transformation of madrasa in Thailand cannot be separated from the teaching and learning processes in madrasa. The madrasa has shown a great amount of growth 
in teaching religious values and cultural diversities which are two of the most important factors in Thailand since it is not a Muslim-majority country (Raihani, et al. 2016). However, there needs to be more papers studying on these phenomena so that madrasa can grow bigger and more people will have positive points of view towards madrasa in Thailand.

\section{CONCLUSION}

Ponok in Southern Thailand is the forerunner of modern Islamic schools which is a result of the enactment of reforms in all fields by Thai central government in 1902. As educational reforms entered the Muslim Malay community, they are asked to read and write in Thai Language and oriented towards secular subjects and even to Buddhism. Madrasa can actually be considered "a corrector" of ponok. When ponok first emerged, people had a bad stigma about it; it is a place to spread out extreme teachings and Islamic values and hatred towards other religions. However, as Islamic education developed into madrasa and formal education is conducted, Islamic education is becoming more inclusive. Some people started to be aware that madrasa implements a modern schooling system as well.

In the history of the establishment of madrasa, a modern Islamic school, at least there are three causes: First, The intervention of central government to reform in all fields, Second, The adoption of a single legal system by the central government (the abolition of Islamic law and Malay customary law which had become the basis in everyday life practice), Third, The Islamic modernist movement brought by the santri of ponok who studied in Mecca, and upon their return established the modern Islamic school of madrasa. Those three aspects contribute a lot to the development of Islamic education in general in Thailand. Nowadays, Islam is believed to expand in a more positive value among people.

There are three background factors of the establishment of madrasa in Southern Thailand, they are; First, Islamic modernist movement, Second, Central governmental intervention about the implementation of reforms in all fields, Third, the effort to improve the socio-economic life of Muslim Malay community in Southern Thailand through education.

\section{BIBLIOGRAPHY}

Andre, V. (2008). Southern Thailand: A cosmic war? In radicalisation crossing borders: New directions in Islamist and jihadist political, intellectual and theological thought and practice. GTReC Proceeding. p. 89-169. Retrieved from http://artsonline.monash. edu.au/gtrec/ files/2012/08/gtrec-proceedings-2008-08-virginie-andre.pdf

Aphornsuvan, T. (2003). History and politics of the Muslims in Thailand. Thamusat University. Retrieved from https://www.researchgate.net/ publication/ 267702487_History_ and_ Politics_of_the_Muslims_in_Thailand

Arphattananon, T. (2011). Education for culturally diverse students in Thailand: The case of Muslim students in the southernmost provinces. The International Journal of Learning: Annual Review, 17(10). https://doi.org/10.18848/1447-9494/CGP/v17i10/47285

Aslam, M. M. (2008). The Southern Thailand insurgency: Ideological and identity challenges. Journal of Southeast Asian Studies, 13(1). Retrieved from https://www.researchgate.net/ publication/265270788_the_southern_thailand_insurgency_ideological_and_identity_ch allenges

Azra, A. (2002). Ensiklopedia tematis dunia Islam, Asia Tenggara. Jakarta: PT. Ichtiar Baru.

Bashori, B. (2017). Modernisasi lembaga pendidikan pesantren. Jurnal Ilmu Sosial Mamangan, 6(1), 47-60. https://doi.org/10.22202/mamangan.1313

Esposito, J. L. (1995). Ensiklopedi oxford dunia Islam modern jilid 6. Bandung: Mizan. 
Firdaus, \& Wekke, I. S. (2017). Pattern of pesantren on expanding of smart, hardworking and ikhlas characters in West Suamtera (p. 258-265). In Seminar Pendidikan Transdisiplin (STEd 2017). Retrieved from https://www.researchgate.net/ publication/319716154_ Pattern_of_Pesantren_on_Expanding_of_Smart_Hardworking_and_Ikhlas_Characters in_West_Sumatera

Haemindra, N. (1976). The problem of the Thai-Muslims in the four Southern Provinces of Thailand (Part One). Journal of Southeast Asian Studies, 7(2). https://doi.org/10.1017/S0022463400015010

Hashim, R. (2011). Traditional Islamic education in Asia and Africa: A comparative study of Malaysia's pondok, Indonesia's pesantren and Nigeria's traditional madrasah. World Journal of Islamic History and Civilization., 1(2), 94-107. Retrieved from https://www.researchgate.net/publication/268255429_Traditional_Islamic_Education_ in_Asia_and_Africa_A_Comparative_Study_of_Malaysia's_Pondok_Indonesia's_Pesant ren_and_Nigeria's_Traditional_Madrasah

Houben, V., \& Schulze, H. (2012). Indonesia Islam und Staat in den Landern Sudostasiens: Islam and state in Southeast Asia. Journal of Southeast Asian studies, 43(22). https://doi.org:/10.1017/S0022463412000185

Ibrahim, M. (2012). Seputar gerakan Islam di Thailand suatu upaya melihat faktor internal dan eksternal. SOSIO-RELIGIA, 10(1), 133-154. Retrived from https://www.aifisdigilib.org/vol-10-no-1-february-2012.html

Islam, S. S. (1998). The Islamic independence movements in Pattani of Thailand and Mindanao of the Philippines. Asian Survay, 38(5), 441-456. https://doi.org/10.2307/2645502

Kraus, W. (1984). Islam in Thailand notes on the history of Muslim provinces, Thai Islamic modernism and the separatist movement in the south. Institute of Muslim Minority Affairs Journal, 5(2). https://doi.org/10.1080/02666958408715910

Liow, J. C. (2005). Islamic education in Thailand: Negotiating Islam, identity and modernity. (p. 121-149). Southeast Asia Education Survey.

Liow, J. C. (2009). Transnational Islam in south and southeast Asia: Movements, networks, and conflict dynamics. In Local networks and transnational Islam in Thailand (with emphasis on the southernmost provinces). In Transnational Islam. Retrieved from http://nbr.org/publications/issue.aspx?id=195

Lubis, M. A., \& Wekke, I. S. (2016). Integrated Islamic education in Brunei Darussalam: The hopes and challenges. EDUCARE, 1(2). Retrieved from http://www.mindamasjournals.com/index.php/educare/article/view/198

Madmarn, H. (2009). The pondok \& madrasah in Pattani. Malaysia. Universiti Kebangsaan Malaysia.

Man, W. K. C. (1985). The Malay- Muslims of Southern Thailand. Institute of Muslim Minority Affairs Journal, 6(1), 98-112. https://doi.org/10.1080/13602008508715927

Rabasa, A. (2005). Islamic education in Southeast Asia current trends in Islamist ideology (Vol. 1-2). Washington. Retrieved from https://www.hudson.org/ content/ researchattachments/ attachment/1453/ current_trends_islamist_ideology_v2.pdf

Raihani, R., Karim, P., Asyari, S. M., \& Mahnun, N. (2016). Delivering Islamic studies and teaching diversity in Southern Thai Islamic schools. Al-Jami'ab: Journal of Islamic Studies, 54(1), 123-146. https://doi.org/10.14421/ajis.2016.541.123-146

Sarkar, D. (2014). Religious minority, education and separatism in South Thailand. In 12th International Conference on Thai Studies. Sydney: University of Sydney. Retrieved from https://sydney.edu.au/dam/corporate/documents/sydney-southeast-asia-centre/ictsprogram.pdf 
Sateemae, S., Abdel-Monem, T., \& Sateemae, M. (2015). Religiosity and social problems among Muslim adolescents in southern Thailand. Journal of Muslim Mental Health, 9(2), 3-24. https://doi.org/DOI: http://dx.doi.org/10.3998/jmmh.10381607.0009.201

Von-Feigenblatt, O. (2010). The Muslim Malay community in Southern Thailand: A "Small people" facing existential uncertainty. Ritsumeikan Journal of Asia Pacific Studies, 27, 53-63. Retrieved from https://papers.ssrn.com/sol3/Papers.cfm?abstract_id=1589021

Wekke, I. S. (2015). Antara tradisionalisme dan kemodernan: Pembelajaran bahasa Arab madrasah minoritas Muslim Papua Barat. TSAQAFAH, 11(2), 313-332. https://doi.org/DOI: http://dx.doi.org/10.21111/tsaqafah.v11i2.271

Wekke, I. S., \& Sahlan, A. (2014). Strategy in creating school environment: Lessons from high schools in Indonesia. Procedia-Social and Behavioral Sciences, 143, 112-116. https://doi.org/10.1016/j.sbspro.2014.07.370

Yong, K. W. (2012). There are ponoks, and there are ponoks: Traditional religious boarding schools in Thailand's Far-South. Advances in Anthropology, 2(3), 161-168. http://dx.doi.org/10.4236/aa.2012.23019

Yusuf, I. (1999). Aspects of Islam in Thailand today. ISIM Newsletter, p. 3.

Zakaria, I. (2012). Islam dan falsafahnya dalam kebudayaan melayu (Islam and its philosophy in Malay culture). Jurnal Hadhari: An International Journal, 91-108. Retrieved from http://journalarticle.ukm.my/6100/1/JD005862_91-108.pdf 